\title{
MJN AT THE CROSSROADS: THE UNHEARD VOICES OF CONTRACTUAL NURSES
}

\author{
Dhona Flor L. Garcia' ${ }^{1}$, Julius C. Daño²* \\ Cebu Normal University, Philippines \\ *Corresponding Author's Email: juliuscoloniadano@gmail.com
}

\begin{abstract}
Contractualization of nurses is rampant in the Philippine public health system. With the current situation, the main concern of the nurse administrators is the retention of nurses in the workforce which is very critical for health system performance. This study explores the stories of contractual nurses who have worked and resigned in hospitals. The study adopted a longitudinal qualitative case study using interpretive narrative method. It utilized purposive sampling since it involved participants with experience regarding the phenomenon of interest. The data were analysed in two stages. Holistic-content method of life story and a thematic approach to narratives. The themes emerged include "More, More, More" means lack of financial support, Between "You and Me" connotes lack of healthy peer relationship, "Work, Work, Work" indicates stressful work demands, "Across the Green Pasteur" signifies better opportunities outside the hospital and "I Need You" entails no administrative attention. Among variety of reasons of resignation of the contractual nurses from their job mainly included economic, political, emotional/psychological and social factor that greatly affects the person as a whole. The results are beneficial to the hospital administration in addressing nurses' retention.
\end{abstract}

Keywords: Contractual nurses, Resignation, Retention

\section{INTRODUCTION}

In a time of nursing shortages nationally here in the Philippines, a disturbing number of young registered nurses have expressed a willingness to leave and resign from the profession. In many hospitals particularly in private and government hospitals in the Philippines, there has been an increasing resignation of professional nurses particularly nurses appointed as contractual employee. Their resignations resulted to nursing shortage as observed and inadequate delivery of high-quality health care. Contractualization is rampant in the public health system (Ellao, 2015). Thus, most nurses would opt to work as relievers or substitutes rather than staying jobless. In the Philippines, thousands of nurses are produced by the country every year (Lagrimas, 2011). But relievers/substitute are under an agreement of "no work no pay", and no benefits.

The Philippine Nurses Association (PNA) is now pushing for the implementation of Republic Act 9173 of the Nursing Law that seeks increase of the pay scale of nurses working in government hospitals to Salary Grade 15. Based from Comprehensive Nursing Law of 2016 , as of $15^{\text {th }}$ June 2015, there are 869,612 registered nurses in the Philippines. A total of 71,289 or $8 \%$ of them are working abroad for better pay. Meanwhile, the remaining $92 \%$ are working here in the Philippines and receiving meagre salaries. For hospital nurses, entrylevel employment which is Salary Grade 10 provides them with PI7, 255.00 a month. Meanwhile, for nurses working under the local government units, they receive a daily wage ranging from P191.00 to P295.00. These amounts are not commensurate to the level of work that they do. This is one of the reasons why many of our nurses prefer to work abroad to provide for their families (Trillanes, 2016).

In the government sectors, the temporary work service or contractual service covers less than six months according to the law of contract. But their salary is higher compared to private hospitals. Meanwhile in the private sectors, contractual nurses are recruited for 
the purposes of providing patient care, but their salaries are minimal with few privileges and benefits. But the reasons they hire contractual nurses so that the hospital can save expenses without compromising their human resources, instead of hiring nurses to a permanent position, they let them work as contractual or as reliever. This means, nurses who are under job order or signed as contractual do not have the same benefits as the regular employees (Speak, 2016).

According to Ellao (2015), there are at least 200,000 unemployed registered nurses and 130,000 health workers in the public health care system. But Balita (2016) argued that there is no oversupply of nurses in the Philippines. There is under-utilization. In both government and private, nurses are overworked in terms of nurse-to-patient ratio. The Department of Health $(\mathrm{DOH})$ standards ratio for nurse's load in the hospital is 1:10-15. This standard ratio is presently violated by both government and private hospitals. The bed capacities of hospitals have grown but the human resource allocation, which is the number of nurses, has not proportionately increased. This implies to the certainly poor health care service for the Filipino people (Balita, 2016).

The study aims to understand deeply the reasons of resignation of contractual nurses.

\section{Statement of the Problem}

The study aimed to explore the stories of contractual nurses who have worked and resigned in hospitals in the Province of Bohol, Philippines. Specifically, this study answers the following questions:

1. What are the stories of contractual nurses? Why do they resign?

2. What themes emerged from the contractual nurse stories?

\section{METHODOLOGY}

This study adopted qualitative case study using an interpretive narrative method. This method enables exploration of a phenomenon within its perspective utilizing a group of information sources and this guarantees that the issue isn't investigated through one perspective, rather a group of important points which takes into consideration to be comprehended. The research locale of the study were hospitals in the Province of Bohol, Philippines. The study utilized purposive sampling since it looked for participants who were experienced about the phenomenon of interest. This study invited three nurses who were employed and resigned from the hospitals they worked for and they were invited to narrate stories regarding the reason for their application, work experience and resignation. Inclusion criteria consists of a registered nurse who have at least one contractual term and have resigned during the succeeding contract.

During the interview, the participants were asked to narrate their experiences as nurses working in a hospital. Open-ended questions were used to motivate the key informants to narrate their personal experiences or life stories. When the complete stories were obtained, some detailed relevant questions were asked to encourage further elaboration on the narrative. Bracketing is emphasized in this qualitative case study to set aside personal experiences, biases, preconceived notions about the topic to understand the views of the participants.

The data were analyzed in two stages. Firstly, the researcher followed the holistic-content method where the life story of a person was considered (Flinkman, Boret, \& Salantera, 2013). The researcher reported three types of career stories from the narratives based on the interviews. In these narratives, separate events from the nurses' experiences were selected and organized into complete narratives with a chronological order. Secondly, a thematic approach to narratives was used when trying to find common thematic elements. The researcher focused on the identified themes throughout the stories and compared, contrasted, and interpreted these themes in the context of the employment in the hospitals. By presenting the cases and the themes simultaneously, a more holistic and multidimensional perspective of these stories were reached.

\section{RESEARCH METHODOLOGY}

Table 1 presents the profile of the selected participants (registered nurse) in terms of age, gender, status, educational qualification and employment status. All the participants are single, registered nurses and out of the three selected participants there is only one female. They worked as contractual nurses in the hospitals of Bohol, Philippines. 
Table 1: Profile of the Participants

\begin{tabular}{|l|l|l|l|l|l|}
\hline Participants & Age & Gender & Status & $\begin{array}{l}\text { Educational } \\
\text { Qualification }\end{array}$ & $\begin{array}{l}\text { Employment } \\
\text { Status }\end{array}$ \\
\hline John (Pseudonym) & 31 & Male & Single & $\begin{array}{l}\text { Registered } \\
\text { Nurse }\end{array}$ & $\begin{array}{l}\text { Contractual } \\
\text { Nurse }\end{array}$ \\
\hline Anna (Pseudonym) & 27 & Female & Single & $\begin{array}{l}\text { Registered } \\
\text { Nurse }\end{array}$ & $\begin{array}{l}\text { Contractual } \\
\text { Nurse }\end{array}$ \\
\hline Dan (Pseudonym) & 27 & Male & Single & $\begin{array}{l}\text { Registered } \\
\text { Nurse }\end{array}$ & $\begin{array}{l}\text { Contractual } \\
\text { Nurse }\end{array}$ \\
\hline
\end{tabular}

\section{Starting the Stories: Introducing the Career Story Narrators}

\section{Case A}

John (a pseudonym) who worked as a contractual nurse in a government hospital in Bohol, Philippines was at the breaking point in his nursing career in which he decided that a critical decision to resign from the institution where he's working must be made. The participant showed a strong intention to resign yet at the same time he was concerned because he was not sure what opportunity waits for him if he do so. John (name changed) was very logical yet emotional and told his story in both reasonable and emotional way. His narrative was detailed, complex, and often include cynical statements and hurtful experiences in the hospital because he was suspended from work for 1 month due to a medication error he was involved in.

\section{Case B}

Anna (a pseudonym) who worked and then resigned from a private hospital. Her choice to transfer in a government institution made her resign from the private hospital where he was working. She told her story in a good-humor, often laughing. Throughout her story, she mentioned repeatedly that her nursing job had mostly been "well" even though the private patients and doctors were very demanding regarding their service. The very reason why she resigned from private hospital was that she aimed to get a permanent position in the government hospital and to earn higher salary.

\section{Case C}

Dan (a pseudonym) who worked and resigned in the government hospital. He was very calm and analytical when telling his story during the interview. His narratives were well structured and used a smooth narrative style to tell his stories. He enjoyed the workloads in the medical ward where he was assigned especially in taking care of the patients despite the low salary he received because he was familiar with the tasks in the ward. However, the negative attitudes of his co-workers pushed him to resign from the hospital because he couldn't accommodate with the treatment that he received there. He found it unhealthy to continue working in the hospital because there was no decent relationship and work culture with his co-workers because of their attitudes.

\section{RESULTS}

\section{Thematic Findings}

There are five themes identified from the stories narrated by the participants based from the interview conducted.

\section{Theme One: More, More, More}

From the beginning of his nursing career in a government hospital John received a salary of 250.00 pesos per day ( $\$ 5 /$ day) and after 2 years it was raised to 350.00 pesos ( $\$ 7 /$ day). His contract provided a condition of "no work, no pay." That means, if he failed to work for any reason, he will not receive any payment from the hospital. However, he felt that the amount cannot compensate to the job demands. He recalled

"Our salary was low, we were not compensated. But in the name of public service, I am extending my patience. What is important is we can help other people.

Ann (a pseudonym) said that the salary she received in the private hospital was enough for herself, but she also claimed that her salary was not enough to support her family's needs. She recalled

"My salary there was fine, and it was only enough for me. Even if I contributed to our family in terms of financial assistance in the household expenses but still it's not enough."

Dan (a pseudonym) claimed that his salary was below the minimum wage. He received a monthly salary of P6500.00 to P7000.00 per month (\$140/month) which is far below the minimum wage according to law which is P14, 000.00 per month. Due to his low salary, he couldn't cope with all his expenses. He further claimed that in many instances, he still requested for financial support from his parents. He recalled what his mother frequently said before 
"You are working butyou're still asking money".

\section{Theme Two: Between "You" and "Me"}

John claimed that the peer he worked with cannot be trusted. They reported secretly to the nurse managers if they noticed mistakes in the nursing tasks. He felt he was not wanted by his peers. It reached to a point that he was immediately suspended from work after being involved with a medication error. He recalled

"Ifelt I was being betrayed by the persons I already treated as my family and I lost my drive to stay in the hospital during that time because I felt that I was not appreciated."

Anna felt that he was not given the opportunity of rotation duty in her preferred area which is in Intensive Care Unit. She felt that favoritism is rampant in the practice of nurse managers. According to him the nurse managers were biased and paid attention according to liking and paid heed to their request. With this, she felt ignored and not liked. She claimed

"I was hurt when I discovered that there was a newly hired nurse who was immediately assigned in the ICU."

Dan narrated his encounters with his peers at times when work became stressful. He found his peers being rude and vindictive. He considered it very difficult to engage with and recalled

"It came to a point that we were having conflicts, we argued in the division of tasks and they started to give comments on me regarding the way I worked and also they were talking behind my back. They even created issues against me which are not true and one of the things I hated the most was they invaded my personal and private life."

\section{Theme Three: Work, Work, Work}

John described the work conditions he experienced as exhausting and stressful. According to him the hospital lacked nurses to cater all patients. As experienced, one nurse is loaded with thirty or more patients per shift and for him that was too much. He claimed

"So far we had 60 patients in our ward and only two nurses on duty. Where is the proper nurse-patient ratio in it? I cannot deny that there were errors and delay in carrying the doctor's orders. There were no room for ideal nursing care."

Anna described the stressful experience she had in working in a private hospital. She observed that the medical staffs like doctors were very demanding especially in assisting them with their patients.

"Every time the Doctors were giving rounds, you must immediately sustain them the necessary information they needed about the patients."

Dan claimed that his job experience was stressful. The workloads in the ward surprised him because it was never detailed in the orientation. The overtime came when the incoming shift nurses were absent. He recalled

"I am assigned in the medical ward and it was really busy catering patients with different diagnosis and duties were shifting. We had 8 hours duty and sometimes 16 hours straight. After which, Irealized that I was burn out because the work was very tiring."

\section{Theme Four: Across the Green Pasteur}

John realized that working in the hospital with poor working condition was not conducive for professional growth. After resigning from the hospital he worked and applying in Rural Health Unit under Department of Health, he found it more promising to his nursing career. He recalled

"We will find a place where we can earn and grow and most especially where we can be happy."

Anna resigned from the private hospital she worked for eleven months. She felt that working in a government owned hospital gives more opportunities to grow and has higher possibility of getting a permanent position. She recalled

"I was encouraged to transfer because I knew that the salary in the government hospital is higher compared to salary in private hospital most especially if you're are having a permanentposition."

Dan was able to differentiate the work demands from the hospital to the Rural Health Unit. He sees better work conditions compared in the hospital as having toxic work activities. He recalled

"I realized that I like more Public Health Nursing 
compared to the hospital-based nursing. Practically, this is what I am looking for to earn more that's why I decided focusing on this job in which I could earn and save more."

\section{Theme Five: I Need You}

All these nurses expected that nursing profession was promising to their personal lives. However, the present situation was not according to their expectation. According to John he lost his interest working in the hospital because he felt his right has been dishonored. He was not given the opportunity he deserves in order to defend himself from the accusations against him. He recalled

"They suspended me for 1 month, I was really hurt for there was no due process made for it. There should be a proper investigation to be conducted. I believed that time, my right to explain the incident wasn't given to me."

Anna believed that there was a discrimination or favoritism of nurse supervisors to their respective employees. She wasn't given the opportunity to be rotated in the Intensive Care Unit which she desired. She was retained in the Medical Ward. For her, it was an unfair treatment. She recalled

"I told the supervisor of the Intensive Care Unit that I am interested in that area. She then guaranteed me that in the next rotation I will be rotated there and all I need is to remind her at the time of next rotation, but it did not happened."

Dan said he lost his interest to work because he felt his supervisors did not make any effort to motivate them amidst the difficult times in the ward but rather recognized only the mistakes they made. He felt that managers in the hospital did not actually understand how demanding the nurses' work and they had very unrealistic proposals about how to develop patient care. He recalled

"Supervisors were demanding us to do better even though they knew the real scenario in the hospital."

\section{DISCUSSION}

The inquiry produced five detailed accounts of the contractual nurse's experiences regarding the working environment in the hospital. The results of this qualitative case study reflected insights into understanding why contractual nurses are resigning in hospitals.

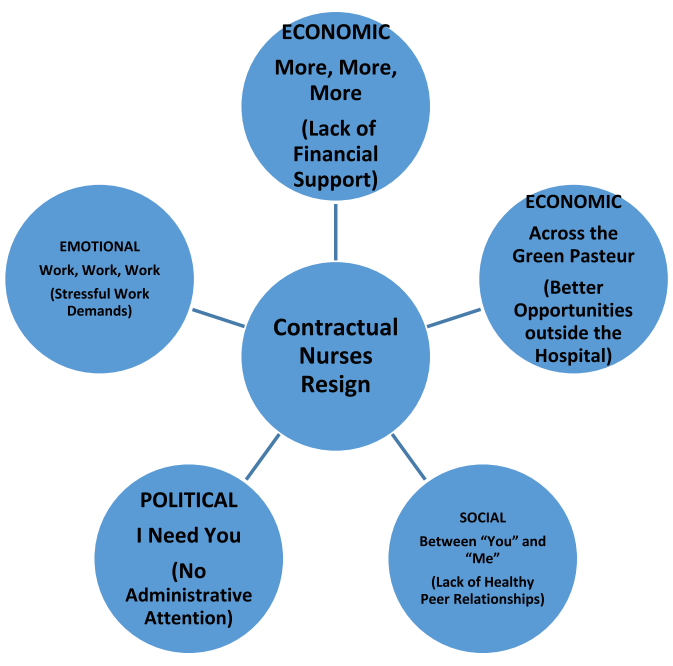

Figure 1: Framework of Contractual Nurses Resigning in Hospitals

Each of the stories narrated by these contractual nurses have its own uniqueness but also depict similarities (see Figure 1). These nurses have great respect and admiration for the nursing profession. They find it very challenging and dignifying since they see nursing as genuine service to humanity. However, there are many conditions affecting them especially in the line of work of these contractual nurses.

Theme One : "More, More, More" means lack of financial support Salary which is in line with the economic needs of a person (they faced financial crisis based on their stories). Their stories depict the condition under which the nurses were forced to resign amidst the low financial support coming from the employers. According to Shamsuzzoha \& Shumon, (2007), poor compensation is widely known as one of the problems in the organization that leads to employee turnover. One of the most common reasons given for leaving the job is the availability of higher paying jobs. This implies that employee leaves the current organization to gain better payment from other organization.

Theme Two: Between "You" and "Me" means lack of healthy peer relationship affecting their social needs. The stories of these contractual nurses revealed an emotional sensitivity that made them to resign. They narrated that peers are also the source of desperation as 
they were not inspiring but a source of conflict. Alike the study of MacKusick \& Minick (2010) revealed that nurses leave clinical nursing practice because they felt a lack of support arising from their peers. Every human being felt the need to be valued and nurses is not an exemption. The nurse managers and the peers in the professional field are needed to uplift and motivate junior nurses during work.

Theme Three: "Work, Work, Work" in this study means stressful work makes the nurses emotionally weak. As seen in this investigation, they were exposed to a stressful situation. It was found that caring for higher number of patient creates a load and work demands are very stressful. These stressful situations is usually followed by overwhelming fatigue and exhaustion. Like the study of Yick \& Chien (2016) revealed that nurses with high moral distress have been related with job dissatisfaction leading to nursing disintegration in the professional life.

Theme Four: "Across the Green Pasteur" means better opportunities outside the hospital which is also in line with their economic needs. In the study it was evident that they resigned because they see better working conditions with higher salary in other institutions compare to the hospital they are working. The study of Berg (1999) and Cortes \& Pan (2012) showed that better pay and better work conditions influence them to work especially in foreign countries. Salaries and workload maybe a considering factor to work in another institutions.

Theme Five: "I Need You" mean no administrative attention which is affecting the job politically. The contractual nurses expressed the need for equal attention and fair recognition from the hospital administration towards all employees. Without due recognition, nurses felt they are not valued. However, Masum et al., (2016) study revealed that satisfaction with supervisory support increases job retention. These contractual nurses find recognition as a significant factor for job satisfaction.

The results of this study are substantial for two reasons. Firstly, the contractual nurses were given a chance to share their own story regarding the reason of their resignation and their resignations from work have rarely been explored from nurse's viewpoint. Secondly, a better piece of this study is its longitudinal nature, which allows the nurses and other readers to follow why contractual nurses resign. These real-life contextual knowledge of contractual nurses' decision of resigning from work can be used as a basis for designing strategies to sustain the nursing workforce.

\section{CONCLUSION}

There are varied reasons why contractual nurses resigned from their job and it is because of economic, political, emotional/psychological and social factor which affects the person as a whole. The results are beneficial to the hospital administration in addressing nurses' retention.

\section{RECOMMENDATIONS}

It is recommended that the hospital administrations should strongly work on strengthening the retention mechanisms by recognizing the needs of the contractual nurses by providing good orientation program at the beginning of their job, giving fair and equitable treatment, scheduled rotation of nurses to different areas in the hospital and in-service training program for professional growth. The organizations should revise its payment system in order to compensate the kind of work nurses do. The chief nurses should propose to the governing bodies of the hospitals to hire additional nurses based on ideal nurse-patient ratio from standards of Department of Health to prevent exhaustion and job dissatisfaction.

\section{REFERENCES}

Balita, C.E. (2016). Open Letter Of Dr. Carl Balita: 'Philippine Nursing Is Dying'. Retrieved from https:// philnews.ph/2016/06/17/open-letter-carl-balita-nursing

Berg, A. (1999). Nurses resign to seek better pay and condition. Retrieved from :https://www.eurofound. europa.eu/ observatories/eurwork/articles/workingconditions/nurses-resign-to-seek-better-pay-andconditions.

Cortés, P. \& Pan, J. (2013). The Relative Quality of Foreign-Educated Nurses in the United States. The Journal of 
Human Resources, 50(4), pp 1009-1050.

Ellao, J.A. (2015). Contractualization in public sector, rampant and anti-worker - workers union. Journalism for People. Retrievd from: http://bulatlat.com/main/2015/02/26/contractualization-in-public-sector-rampantand-anti-worker-workers-union/

Flinkman, M., Bouret, U. \& Salantera, S. (2013). Young Registered Nurses' Intention to Leave the Profession and Professional Turnover in Early Career: A Qualitative Case Study. International Scholarly Research Notices, 2013, pages 12.

Lagrimas, M. (2011). Nursing Shortage in the Philippines. Retrieved from: http://fnf.org.ph/talakayan/ liberal_topic.php?id=1646

MacKusick, C. \& Minick, P. (2010). Why Are Nurses Leaving? Findings From an Initial Qualitativ Study on Nursing Attrition. Medsurg Nurshing:official journal of the academy of medical-surgical nurses, 19(6), pp 225-340.

Masum, A.K.M., Azad, A.K., Hoque, K.E., Beh, L.,Wankee, P. \& Arslan,O. (2016). Job Satisfaction and Intention to quit :an emperical analysis of nurses in Turkey. Peer Journal.

Shamsuzzoha, A.H.M. \& Shumon, M.R.H. (2007). Employee Turnover- a Study of its Causes and Effects to Different Industries in Bangladesh. Manufacturing Engineering/Vyrobne Inzinierstvo, 6(3), pp 64-68.

Speak, R. (2016). 10 Cases of Abuse Filipino Nurses Suffer from their own Country. Retrieved from: http://rnspeak. com/nursing-blog/abuse-filipino-nurses/

Trillanes, A. (2016). An Act Providing for a Comprehensive Nursing Law Towards Quality Health Care System and Appropriating Funds. Republic of the Philippines Seventeenth Congress First Regular Session. Retrieved from: https://www.senate.gov.ph/lisdata/2351220115!.pdf

Yick, S. \& Chien, W. (2016). An Investigation of Nurses' Job Satisfaction in a Private Hospital and Its Correlates. The open nurshing Journal,10, pp 99-112. 